\title{
水吅き下流護床工の石碟間詰めによる 落差エ下部パイピング対策の研究
}

\section{STUDY ON COUNTERMEASURES OF GRAVELS AMONG BED PROTECTION WORKS IN DOWNSTREAM OF APRON FOR PIPING UNDER FALLING WORKS}

\author{
川口広司 $1 \cdot$ 末次忠司 $2 \cdot$ 日下部隆昭 3 高田保彦 4 \\ Hiroshi KAWAGUCHI, Tadashi SUETSUGI, Takaaki KUSAKABE and Yasuhiko TAKADA \\ 1正会員 博(工）国土交通省 国土技術政策総合研究所 河川研究部 河川研究室 研究官(テ305-0804 茨城県つくば市旭1) \\ 2正会員 工博 国土交通省 国土技術政策総合研究所 河川研究部 河川研究室 室長(同上) \\ 3正会員 国土交通省 国土技術政策総合研究所 河川研究部 河川研究室 主任研究官(同上) \\ 4正会員 (株)建設技術研究所 水理砂防センター 水理室（テ305-8561 茨城県つくば市鬼ヶ窪1047-27）
}

\begin{abstract}
Bed protection works are constructed for protection of local scour and as energy absorber in downstream of falling works. If hydraulic gradient in bed material were over standard value, seepage control seat would be designed for piping under the falling works. The hydraulic gradient is estimated by use of difference of water levels in upstream and downstream of the river crossing structures. But the hydraulic gradient may increase by bed deformation in down stream of the river crossing structures after the construction. And in the case of low density of concrete blocks of bed protection works, pressure would come down by separate flow in the downstream end of apron.

In this paper, it is examined that causes of piping under falling works and countermeasures of gravels among bed protection works in downstream of apron by large-scale hydraulic experiment.
\end{abstract}

Key Words : Countermeasures of gravels, Bed protection works, Falling works, Piping, Separate flow, Large-scale hydraulic experiment

\section{1. 序論}

護床工は落差工下流で生じる局所洗掘の防止や，高流 速の減勢のために設計される. 護床工の長さは跳水によ り流水のエネルギーを確実に減勢できるように決められ る. 護床工の構造は河床変動に追随できるように屈撓性 を持たせて設計される. 河川横断構造物の本体及び水叨 き下部は，パイピングが起こることを防ぐため，条件に 応じて遮水板が設けられる. 遮水板は構造物上下流の水 位差と浸透路長から算出されるクリープ比が基準值より 小さくならないように設計される1). しかし，河川横断 構造物は設計後の河床変動により外力が想定以上になる 可能性が十分にある. 古い既設構造物は基準を満たして いないこともある．点検，維持管理や補修を行い，構造 物の力学的安定性を確保して既設河川構造物の被災を減 じることが求められている.

河川横断構造物の施工後に下流河床が低下して護床工 直下流で跳水を伴う局所洗掘が発生する場合，下流端護
床工直下流の剥離流れが護床工下部河床材料の抜け出し や護床工の流失を引き起こす. また, 護床工の沈下及び 護床工下部の河床材料の抜け出しは護床工敷設範囲の中 上流域でも起こる2). 落差工などの構造物の安全性を検 討する上で重要となる剥離流れによる圧力低下は数值解 析モデルにより説明されつつある3).

護床工ブロック群に間隙が存在し, 洪水時に水吒き下 流で剥離流れにより圧力低下が大きくなる場合, 落差工 工及び水吒き下部の圧力勾配は想定より大きくなり, パ イピングにより構造物下部に空洞化が起こる可能性があ る. 石礫層のフィルター4)5)を護床工の間詰めに用いて, 既設落差工の安全性を確保できれば, 治水面及び経済面 において効果的と考えられる.

本研究は, 護床工上で跳水が発生し, 護床工を構成す るブロックが流失しない条件で大縮尺の移動床模型実験 を行い, 落差工下部のパイピング発生原因と, 水吒き下 流護床工の石磘間詰めによる対策指針について検討する ことを目的とする. 

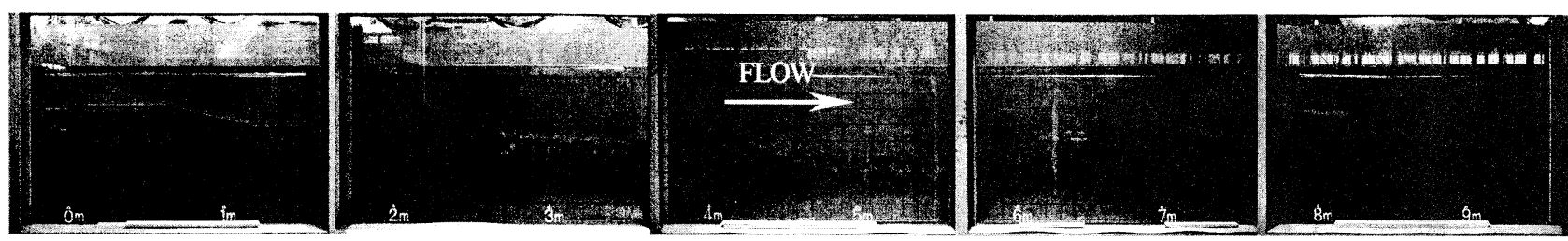

写真-1 落差工及び護床工実験模型 (水路中央10m区間)

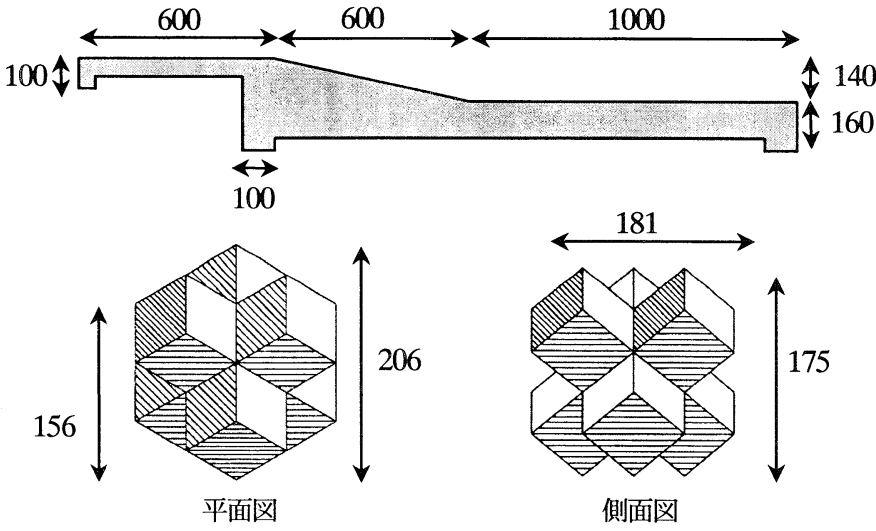

図-1 落差工 及び $2 \mathrm{tf}$ 六脚ブロック $1 / 8$ 模型 (単位: $\mathrm{mm}$ )
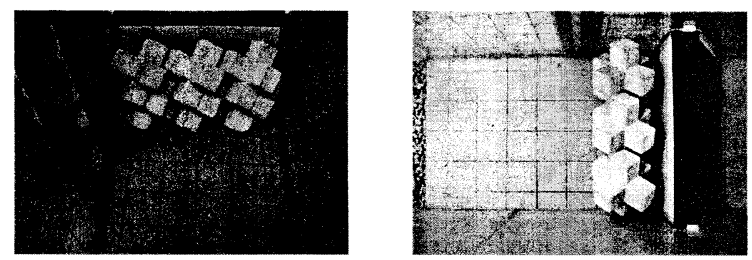

石磘投入前

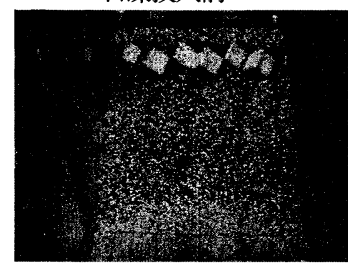

河床材料投入後 $(\mathrm{D}=3 \mathrm{~mm})$

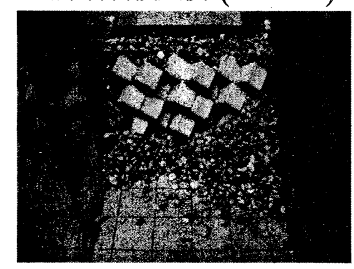

石礫投入後 $(\mathrm{D}=18.9 \mathrm{~mm})$

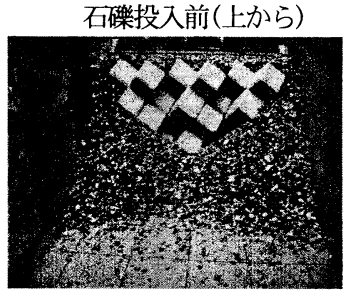

石啋投入後 $(\mathrm{D}=8.6 \mathrm{~mm})$

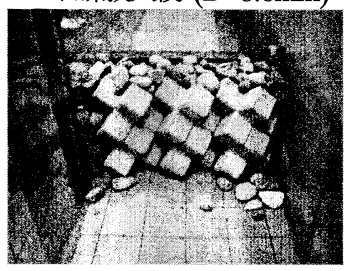

石磷投入後 $(\mathrm{D}=35.5 \mathrm{~mm})$

写真-2 対策工石磁径と護床工ブロック間隙の検討実験

\section{2. 実験方法及び条件}

（1）実験水路, 落差工及ひ護床工模型と測定方法の概要

実験は写真-1に示す落差工及び護床工模型を設置した 移動床直線水路で行われた．水路延長は $18 \mathrm{~m}$ ，水路幅は $0.52 \mathrm{~m}$, 河床材料は $3 \mathrm{~mm}$ のほぼ一様な砂であった. 写真1の距離は落差工模型上流端からの距離であり $\mathrm{x}$ 軸の座標 とする. 右岸ガラス壁面に写る格子幅は $10 \mathrm{~cm}$ である. また，水路床からの高さをz軸座標とする．実験は縮尺

表-1 石礫間詰めの実験諸元 (単位: $\mathrm{mm}$ )

\begin{tabular}{|c|c|c|c|c|c|}
\hline Case & 第1層 & 第2層 & 第3層 & 1層の厚さ & 距離 \\
\hline 1 & \multicolumn{5}{|c|}{ 石磷間詰め無し } \\
\hline 2 & 8.6 & - & - & 100 & 350 \\
\hline 3 & 8.6 & 18.9 & 35.5 & 30 & 950 \\
\hline 4 & 8.6 & 18.9 & 35.5 & 30 & 550 \\
\hline 5 & 8.6 & 18.9 & - & 50 & 550 \\
\hline
\end{tabular}

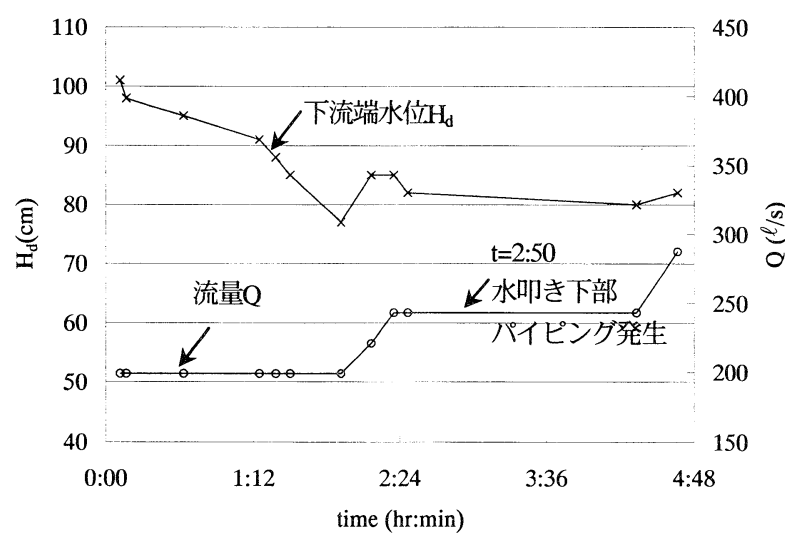

図-2 流量と下流端水位の時間変化 (Case-1)

1/8を想定し, 初期河床形状, 河床材料, 落差工及び護 床工の諸元・設置状況は実河川の既設構造物を参考に決 定した. 図-1に示すように, 落差工模型は延長 $2.2 \mathrm{~m}$, 落 差14cm, 斜面部勾配14/60とした. 落差工上流部の河床 に網を張り，上流の圧力は河床材料中及び下流に伝わり， 落差工下流の河床は静的平衡となるようにした. 護床工 を構成する六脚ブロックの $1 / 8$ 模型(実重量 $2 \mathrm{tf}$, 模型重量 3.9kgf)は, 縦断間隔 $3.8 \mathrm{~cm}$, 勾配 $1 / 20$ で縦断方向に 24 基連 結して, $x=220 〜 748 \mathrm{~cm}$ の範囲に設置した. 六脚ブロッ クは2段に重ねて, 横断方向に3基が等間隔に並ぶように 配置した. 左岸壁面にピエゾメー夕を設置し, 流水中及 び浸透流のピエゾ水頭を測定した，河床材料中右岸には， 染料の出る管を設置し, 浸透流及び水吅き下部の流況を 可視化した. 横断平均水位とブロック高, 右岸側面近傍 の河床高は右岸ガラス面にシールを貼って測定した. 水 吒き下流ではピト一管により $\mathrm{x}$ 方向流速 $\mathrm{u}$ の水路中央鉛直 分布を縦断的に測定した.

\section{（2）実験条件}

表-1は実験に用いた石磁間詰めの諸元を示している. Case1は, 護床工上で跳水が発生している場合に，その 設置範囲における河床が低下し, 落差工模型水吒き下部 がパイピングにより空洞化する状況を把握することを目 的とし，図-2のようにCase1の流量と下流端水位を時間 

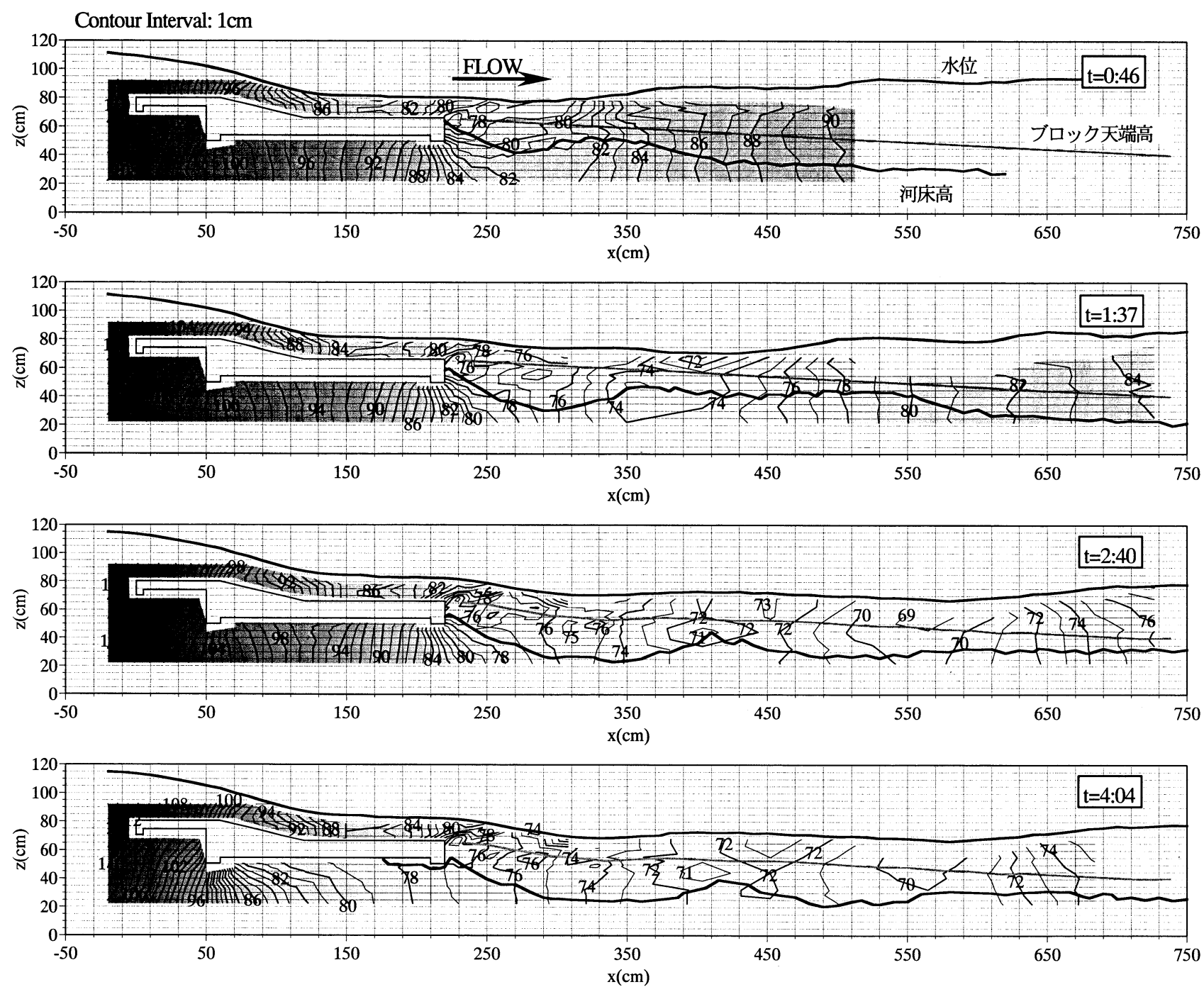

図-3 水位・河床高・ブロック天端高絴断分布とピエゾ水頭コンター (Case-1)

的に変化させた．実験の条件は，落差工上は射流で流れ， 跳水が護床工上で発生し，護床工下流は局所洗掘が発生 しないように設定した. Case2〜5は，初期条件として Case1のパイピングが起きた直後の河床形状及びブロッ ク配置を用い，水吒き下部にCase-1で生じたパイピング による空洞を残した. Case-2〜5の流量は243//s，下流端 水位は $80 \mathrm{~cm}$ とし．流量は現地スケールで単位幅流量 $\mathrm{q}_{\mathrm{r}}=11 \mathrm{~m}^{3} / \mathrm{s} / \mathrm{m}$ に対応する．Case2の護床工の石礫間詰めは 水吒き下流端から一基目と二基目のブロックの間 ( $\mathrm{x}=255 \mathrm{~cm})$ まで1層で, Case3は最深河床 $(\mathrm{x}=315 \mathrm{~cm})$ まで3 層で, Case4,5は再付着点 $(\mathrm{x}=275 \mathrm{~cm})$ まで3層及び2層で 行った．石礫間詰めの層厚は合計約 $10 \mathrm{~cm}$ と，間詰め 下流は層厚を徐々に小さくした．石群間詰め各層の径は ある層の間隙を下層の材料が物理的に通過しない3倍以 内の条件で設定した ${ }^{4) 5}$.

\section{（3）護床工間隙と対策石碟の径}

護床工ブロックが流されない場合，間詰めを行う石砂 は護床工間隙から抜け出ないことが重要である．対策石 砂の径は，写真-2に示す簡易な実験を行うことにより決 定した. 実験では, (1)護床工配置と同様に横方向に2段3
列を固定床上に並べ，(2)その上流に護床工と同じ高さの 木板をたて，(3)木板と護床工ブロックの間に護床工の高 さになるまで石礫を投入した.

河床材料から石礫径を3倍以内で大きくして, ブロッ クの間隙から石砂が出なくなるまで実験を繰り返し行つ た結果，直径 $\mathrm{D}=35.5 \mathrm{~mm}$ の石磁を投入するとブロック下 流に石碟がほとんど流出しなくなった． $\mathrm{D}=3 \mathrm{~mm}$ の河床 材料を投入すると，護床工六脚ブロックの全ての隙間か ら砂が流出し，ブロック下流には勾配が一定，安息角の 斜面が形成された. $\mathrm{D}=8.6 \mathrm{~mm}$ の石砂の場合，中央六脚ブ ロックからの流出が $\mathrm{D}=3 \mathrm{~mm}$ の場合より減少した. $\mathrm{D}=18.9 \mathrm{~mm}$ の石礫の流出は，隙間の大きな左右岸側から がほとんどであり，中央六脚ブロックの隙間からの流出 は少なかった.

\section{3. 水叨き下部パイピングの発生原因検討}

実験Case-1による水位，河床，ピエゾ水頭の結果を示 し，水吒き下部のパイピング発生原因を検討する. 図-3 は実験開始からの時間 $\mathrm{t}=46$ 分, 1 時間37分, 2時間40分, 4時 


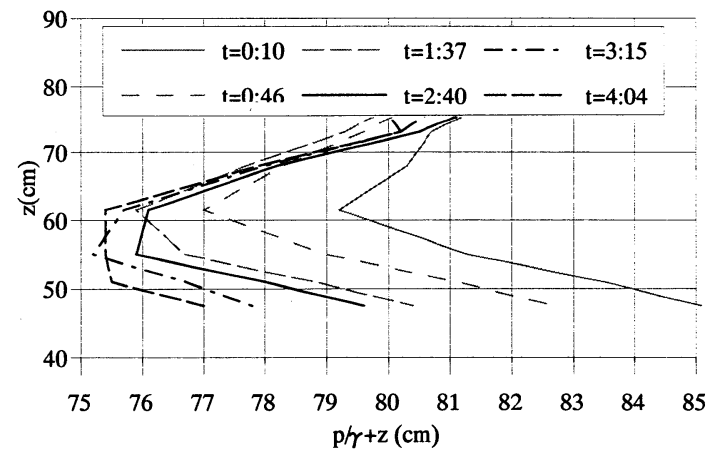

図-4 水叨き下流面ピエゾ水頭変化 (case-1, $\mathrm{x}=220 \mathrm{~cm})$

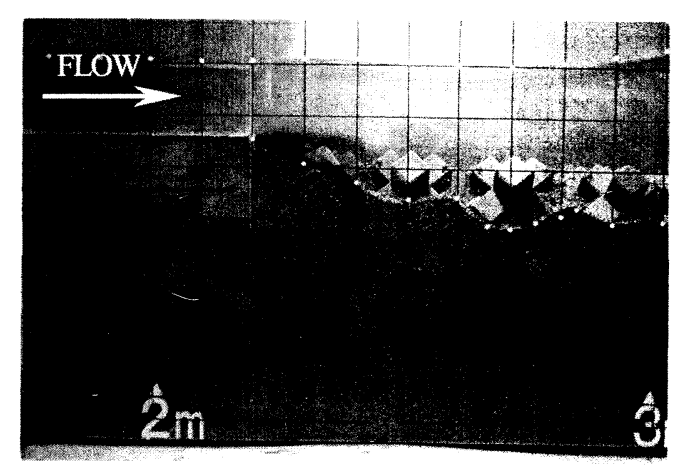

写真-3 浸透流と剥離流れの可視化 (case-1, t=0:10)

間4分 ( $\mathrm{t}=0: 46,1: 37,2: 40,4: 04)$ での横断平均水位, ブ ロック天端高と右岸側壁近傍河床高の縦断分布, 流水と 浸透流のピエゾ水頭コンターを表している. 水叨き下流 の河床は洗掘されて低下し, 流量増加後の $\mathrm{t}=2: 40$ には護 床工ブロックが沈下した. $\mathrm{t}=2: 50$ では水叨き下部でパイ ピングが，落差工水吒き下流面 $\mathrm{x}=2 \mathrm{~m} 20$ から $1,2 \mathrm{~cm}$ の範囲 で河床材料が鉛直上向きに噴き上がることにより発生し た. パイピングによる水吒き下流面の噴砂は, 水路中央 で局所的に起こった10分後, 水吒き下流面全体にわたっ て起こつた.

設定した実験条件において落差工を越える流れは射流 となり, 水面と同様に流線が曲がる.上に凸となる流れ では水面付近で圧力が静水圧より上昇し，下に凸となる 流れでは河床付近で静水圧より増加する. 図-3に示すよ うに，実験Case1の落差工上の水面及びピエゾ水頭は全 ての時間において同様の傾向を示しており, 流量の等し い $\mathrm{t}=0: 46$ と $\mathrm{t}=1: 37$ 及び $\mathrm{t}=2: 40$ と $\mathrm{t}=4: 04$ においてはピエゾ水 頭の值もほぼ同じである. また, どの時間においても,

写真-3のように水吒き上の流れは下流端で剥離を起こし, 水吒き下流面で圧力低下を起こしていた. そのため, 水 叨き下流の河床面付近の流れは再付着点から上流に向 かっていた.

一方, 図-3の落差工下部河床材料中の浸透圧は, 流量, 下流端水位の変化に伴い大きく変化している. 落差工下 流の護床工設置箇所での河床は流量の増加とともに $\mathrm{t}=1: 37$ から $\mathrm{t}=2: 40$ にかけて洗掘が進んでおり, 水叨き下 流面の河床高も低下している. 通水初期の段階では水叨 き下流の再付着点より上下流に向かって河床材料は移動

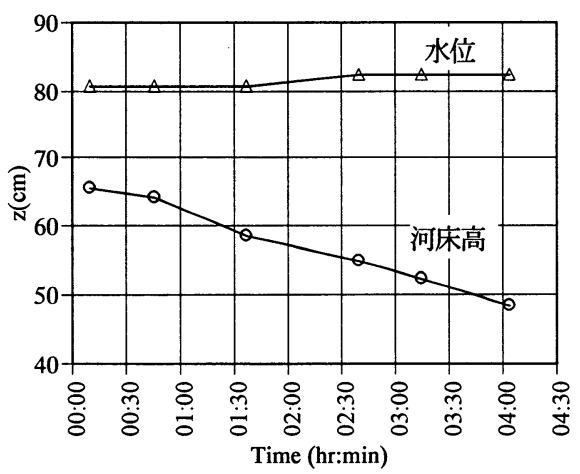

図-5 水吒き下流端での水位·河床高時間変化 $($ case-1, $x=220 \mathrm{~cm}$ )

していたが, 通水後しばらくすると水吒き直下流の河床 は下流斜面の影響を受けて安息角を保つように低下した. また, 図中の落差工直下流のピエゾ水頭も河床の低下 に伴い小さくなっており, $\mathrm{t}=2: 40$ の水吒き下部ピエゾ水 頭勾配はt=1:37より上に向いていることがわかる.

$\mathrm{t}=4: 04$ では水吒き下部でパイピングによる空洞が形成 されており, 水吒き下流端下部 $(\mathrm{x}=220)$ のピエゾ水頭が 大きく低下している. また, 落差工 $(\mathrm{x}=50 \mathrm{~cm})$ の下部で ピエゾ水頭勾配が大きくなっている. この後, パイピン グによる空洞は時間と共に上流に向かって大きくなって いつた.

図-4は水叨き下流面のピエゾ水頭, 図-5は同位置での 水位と河床高の時間変化を示している. 落差工水叨き下 流面は $\mathrm{z}=50$ \% $6 \mathrm{~cm}$ である. Case $1, \mathrm{x}=220 \mathrm{~cm}$ の水位は流 量の増加と共に若干高くなっているが, 河床高は時間と 共に徐々に低下している. 図-3でみられた河床低下にと もなうピエゾ水頭の低下も確認できる. 水叨き下流の洗 掘が進み, 河床が低下して, 落差が大きくなることで, 水吅き下流の剥離流れによる圧力低下が大きくなったた めと考えられる. また，ピエゾ水頭の鉛直分布に着目す ると, 河床高付近で最も小さくなっており, 河床材料中 の圧力低下も大きくなっていることがわかる. 落差工を 越える流れの水面形及び圧力場に大きな変化がみられな いため. 通水初期の段階と比べて浸透流は上に向き, 鉛 直上向きの浸透流速が時間の変化と共に増加したと判断 できる.

水吒き下部のパイピングは下流の洗掘が進み, 下流面 の河床高が低下して，水吒き直下流の剥離流れによる圧 力低下が大きくなり, 鈶直上向きの浸透流の流速が水叨 き下部で大きくなることにより発生したと考えられる.

\section{4. 石礫間詰めによるパイピング対策}

水吒き下流の護床工の六脚ブロックに長さ, 厚さ, 層 数の違うCase-2〜 5の石礫間詰めを行い, 落差工下部パ イピングの対策指針を検討する. Case-2は, Case-1と同 様に水吒き下流面の河床高が低下した後. パイピングが 発生した. 通水後数分は河床材料が剥離流れの強い逆流 


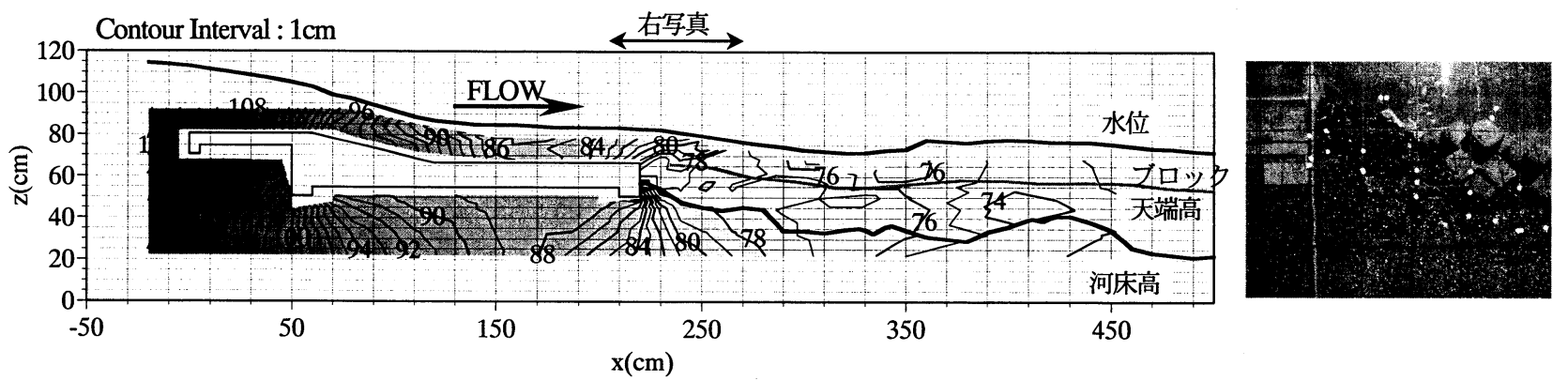

(1) Case-2: $\mathrm{D}=8.6 \mathrm{~mm}, 1$ 層, 長さ $350 \mathrm{~mm}$, 厚さ $100 \mathrm{~mm}$

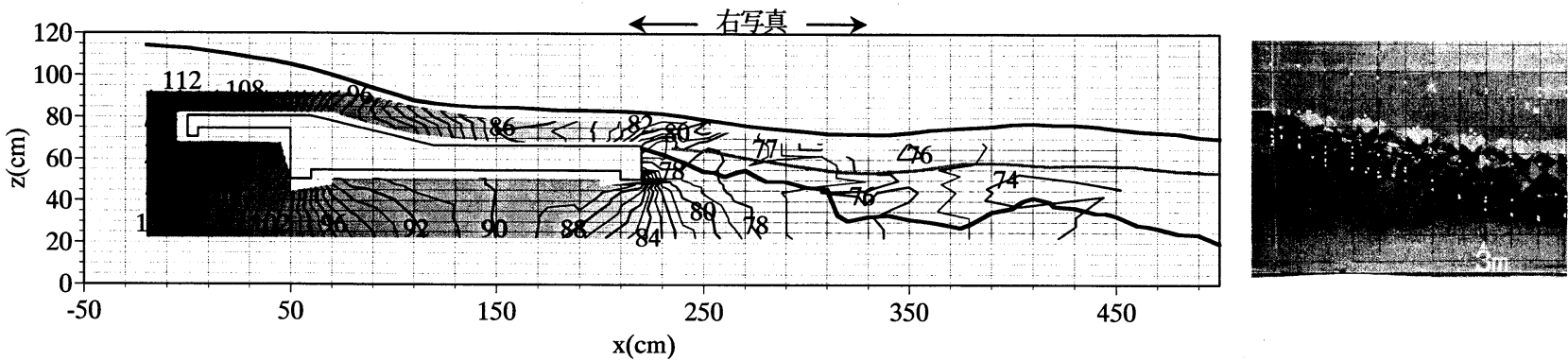

(2) Case-3: $\mathrm{D}_{1}=8.6 \mathrm{~mm}, \mathrm{D}_{2}=18.9 \mathrm{~mm}, \mathrm{D}_{3}=35.4 \mathrm{~mm}, 3$ 層, 長さ $950 \mathrm{~mm}$, 厚さ $30 \mathrm{~mm}$
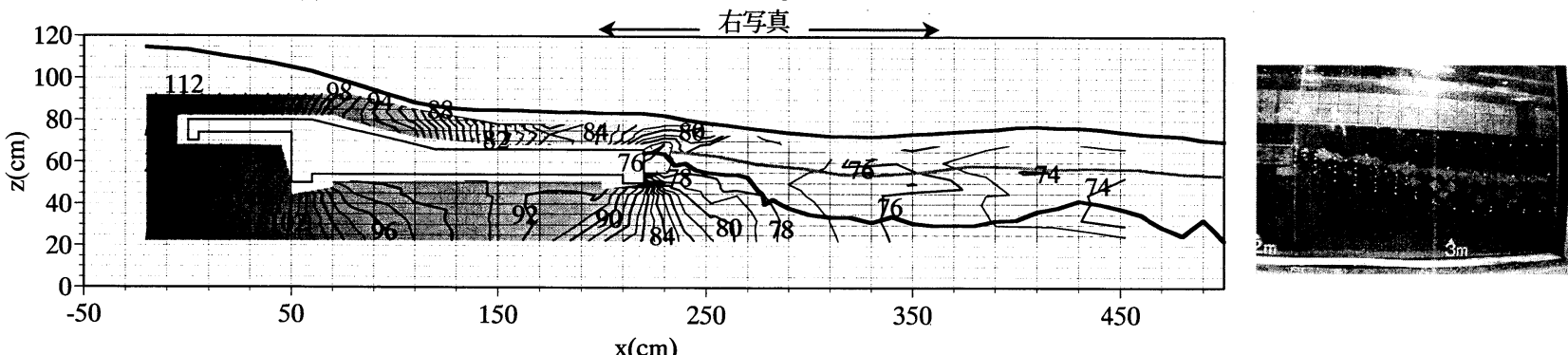

(3) Case- $4: \mathrm{D}_{1}=8.6 \mathrm{~mm}, \mathrm{D}_{2}=18.9 \mathrm{~mm}, \mathrm{D}_{3}=35.4 \mathrm{~mm}, 3$ 層, 長さ $550 \mathrm{~mm}$, 厚さ $30 \mathrm{~mm}$
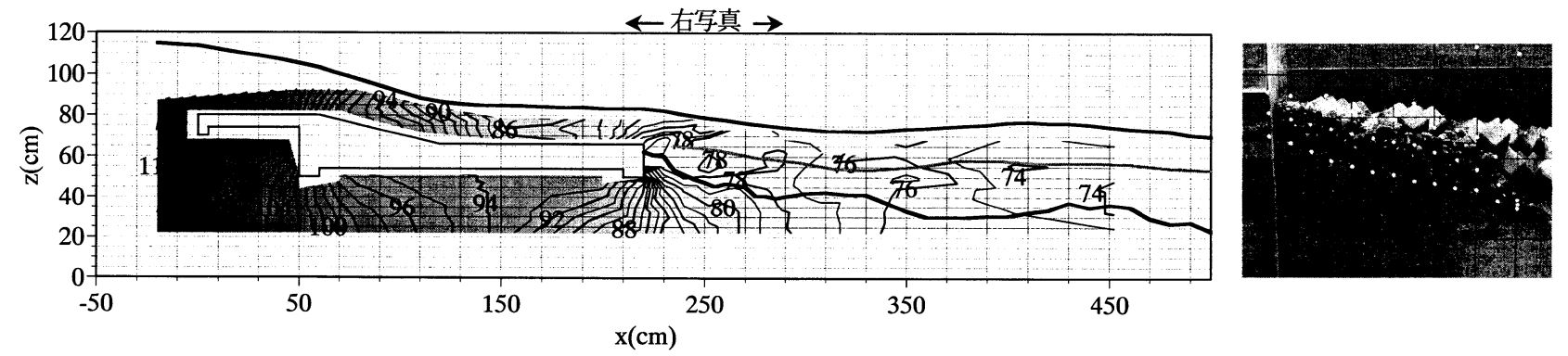

(4) Case-5: $\mathrm{D}_{1}=8.6 \mathrm{~mm}, \mathrm{D}_{2}=18.9 \mathrm{~mm}, 2$ 層, 長さ $550 \mathrm{~mm}$, 厚さ $50 \mathrm{~mm}$

図-6 水位・河床高・ブロック高縦断分布，流水及び間隙水圧水頭コンターと水吒き下流護床工石礫間詰め状況 (Case-2〜5)

による掃流をきっかけとして河床が低下していたが, 数 分後には下流の河床材料及び石碟の移動に伴い安息角を 保つように河床は低下した。

図-6はCase-2～5の水位, 河床高, ブロック高の縦断分 布と流水及び浸透流のピエゾ水頭コンターと水叨き下流 護床工石碰間詰め状況を示している. 水吒き下流の河床 高は対策石碟を含めた高さで表している. Case-2はパイ ピング発生10分前, Case-3〜 5はパイピング対策石碟が 移動して平衡状態亡なった時のものである. Case-2〜5 の水吒き下流の河床形状は対策石礫が下流に流される影 響を受け若干の差があるが，護床工ブロックの天端高が 全て同じであるため, 水面形はほとんど変わらない.

対策後のピエゾ水頭コンターと対策前のCase-1 と比較 すると, Case-2〜 5の水吒き下流端下部でコンターが密
になっていることがわかる. 空洞内の流れが対策石礫内 で減速し水吒き下流端下部ではx方向に沿って圧力が急 に上昇するためである. 染料により可視化した浸透流の 流跡線もピエゾ水頭コンターの最急勾配の方向に沿うよ うに，水吒き下流端下部で下向きに凸となった．落差工 下部に空洞があり，下流の護床工との間に石礫間詰めに よるパイピング対策を行った場合, 対策工の下部の圧力 は上昇し，圧力勾配が大きくなる.

石礫間詰めを行った後のCase-2〜 5のピエゾ水頭コン ターを比較すると全ケースの水吒き下流でコンターと河 床面がほぼ平行になっていること, Case-2,5は水叨き下 流河床面下部でコンターが密になっているがCase-3,4は コンターの間隔が比較的粗になっていることがわかる. また, Case-2,5はコンターが密な箇所と河床面が接近し 


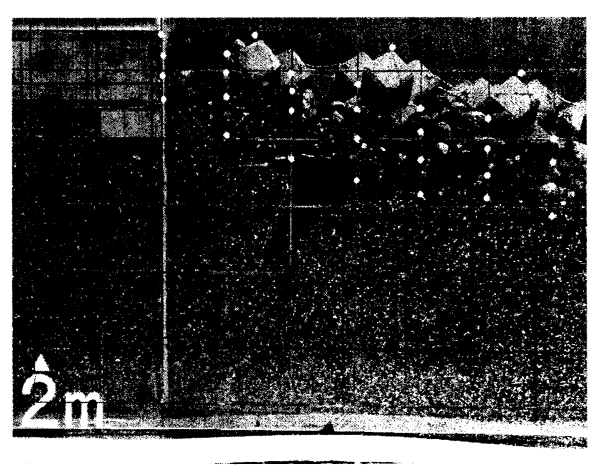

写真-4 浸透流と剥離流れの可視化 (Case-3)

ている. 3層で石磷間詰めを行ったCase-3,4の対策工が流 されなかったのは水吒き下流の河床が低下しなかったた めであり, Case-2の石礫対策工が流されたのは水吒き上 の流れが再付着する箇所の下流で対策工が流され，その 上流の河床が安息角を保つように低下したためである. 一方, Case-5の対策工が流されたのに水叨き下部のパイ ピングが発生しなかったのは, 対策工の石喽が護床工ブ ロックの間隙を通ることがほとんごできず，再付着点の 河床が低下してもその上流の河床が低下しなかったため である.

写真-4は染料によりCase-3における浸透流と剥離流れ の流跡線を可視化したものである. 染料の流出位置は写 真-3と同じである. Case-3はCase-1 と比較して上向きに 流れる浸透流の流量が少なく, 石碟対策工に働く鉛直上 向きの力が小さくなっていたと考えられる.

図-7はCase-4,5において水叨き下流端付近の $\mathrm{x}$ 方向流速 u分布を測定した結果である. $\mathrm{x}=200 \mathrm{~cm}$ での流速 $\mathrm{u}$ がほと んど同じであること, 図-6のピエゾ水頭の分布及び水面 形が同様なことからCase-4,5の落差工上の流れに有意な 差はない.しかし， $x=220 \sim 265 \mathrm{~cm}$ までの水吒き下流の 流速 $\mathrm{u}$ は水吒き天端 $\mathrm{z}=66 \mathrm{~cm}$ より上部では同じであるもの の, ブロック天端付近の流速はCase4が小さくなる. 磕 層が2層のCase-5は3層のCase-4と比べて, 流下方向に浸 透流が河床から多く流出しているためである.

落差工下部のパイピング対策として護床工に石磷によ る間詰めを行う場合，水吒き下流端の鉛直上向きの浸透 流速が小さくなるように層数を多くすること, 対策石砂 が護床工ブロックの隙間を通過しないことが重要である.

\section{5. 結論}

落差工下部のパイピング発生原因と水叨き下流護床工 の石磷間詰めによる対策工の実験的検討により, 以下の

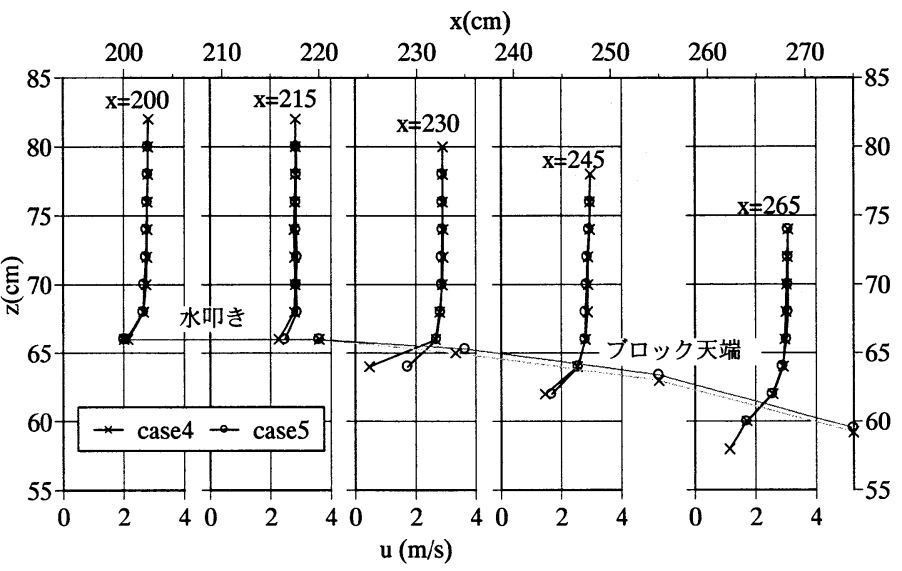

図-7 水吒き下流端付近の $\mathrm{x}$ 方向流速 $\mathrm{u}$ 分布

結論を得た。

1) 落差工下部のパイピングは, 水吒き下流面の河床が 低下し, 水吒き下流端の剥離流れによる局所的な圧 力低下が大きくなることにより発生する. 水吒き下 流面の河床低下は再付着点より下流護床工設置域の 河床が低下することにより安息角を保つようにして 起こる.

2) 落差工下部のパイピング対策として護床エブロック の石礫による間詰めは, 落差工下部の空洞化後も含 めて有効である．パイピングを引き起こす水吒き下 流面の河床低下を防ぐには，水叨き下流端での鉛直 上向きの浸透流速が小さくなるように層数を多くす ること, 対策石磷が護床工ブロックの隙間を通過し ないことが重要である.

謝辞 : 本研究を進めるにあたり，新土木開発(株)の中村公広氏， (株)建設技術研究所の篠原剛氏には多大な協力を得た。ここに 記し感謝の意を表します。

\section{参考文献}

1) (財)国土開発技術研究センター: 床止めの構造設計手引き, 1998.

2) 川口広司·諏訪義雄·高田保彦·末次忠司: 護床工下の河床材 料の抜け出し及び下流跳水の非定常性と護床工の応答特性, 河川技術論文集,第8巻,pp.243-248,2002.

3) 内田龍彦·福岡捷二·渡邊明英・山崎幸栄: 二次元水理構造物 を越流する流れの数值計算, 水工学論文集第47巻,pp817822,2003 .

4) 鈴木幸一, 山本裕規, 栗原崇 : 局所洗掘防止に有効な石磉護 床工の条件, 水工学論文集第39巻，pp695-700，1995.

5) 前野詩朗·藤田修司: 逆フィルターを用いた洗掘防止工に関 する研究,河川技術論文集,第9巻,pp.37-42,2003.

(2003.9.30受付) 